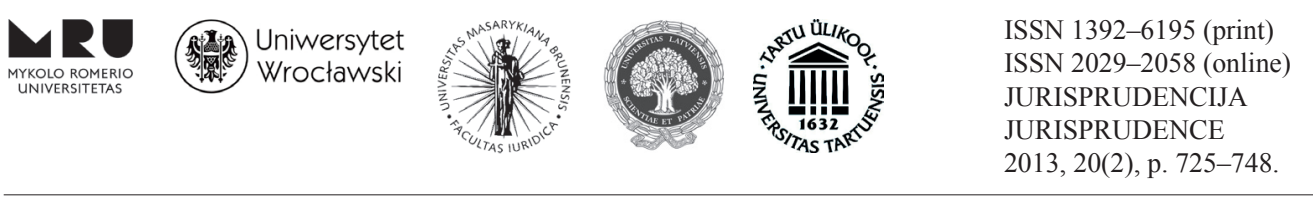

\title{
COMPLETION OF CRIMINAL PROCEEDING WITHIN A REASONABLE TIME IN LATVIA
}

\author{
Sandra Kaija \\ Baltic International Academy \\ Lomonosova street 1, Riga, Latvia, LV-1019 \\ Telephone (+371 2) 6343358 \\ E-mail: skazaka@inbox.lv
}

Received on 27 May, 2013; accepted on 24 August, 2013

doi:10.13165/JUR-13-20-2-20

\begin{abstract}
The paper addresses the issue of a relatively new institution of criminal procedural law in Latvia. The article is relevant due to the need for an effective mechanism for the objective possibility of realization of the right person for the completion of the criminal process in a reasonable time. Analysis of the European Court of Human Rights has allowed some conclusions that should be considered when investigating criminal cases.
\end{abstract}

Keywords: human right, criminal procedure, reasonable time, completion of criminal proceeding.

\section{Introduction}

Nowadays the quality of a criminal proceeding largely depends on the provision of the right to a fair and prompt public trial by an independent and impartial tribunal established by law.

The field of the protection of the right to a trial within a reasonable time is, unfortunately, one of the most exposed legal fields in Europe or in most of the member states of the Council of Europe ${ }^{1}$.

1 Zalar, A. The Right to Trial within a Reasonable Time and Short-Term Reform of the European Court 
The right to a trial within a reasonable time in European legal traditions encompasses both the procedural and constitutional rights simultaneously, which is fully reflected in the current Latvian legal reality.

One of the fundamental human rights specified in Section 8 of the Constitution of the Republic of Latvia implies that the State shall recognise and protect fundamental human rights in accordance with this Constitution, laws and international agreeements binding upon Latvia. The Constitution also guarantees the rights to everyone to defend his or her rights and lawful interests in a fair court.

A similar statement is also provided in Section 6, Paragraph 1 of the European Convention for the Protection of Human Rights and Fundamental Freedoms: "Everyone is entitled to a fair and public trial within a reasonable time by an independent and impartial tribunal established by law when his or her civil rights and obligations are identified or else when he or she faces criminal charges against him or her".

Thus, the European Convention for the Protection of Human Rights and Fundamental Freedoms (hereinafter called the Convention) includes the human right to a fair trial with the special emphasis laid upon the access to this trial within a reasonable time.

Once the Criminal Procedure Law (hereinafter called CPL) enters into force in Latvia, the human right to completion of a criminal proceeding within a reasonable time is ascertained nationally, as well. Following Section 6, Paragraph 1 of the Convention rights to a fair trial, the legislature identifies two separate criminal proceeding principles - the person's right to a fair, independent and impartial tribunal (Section 15 of the CPL) and the right to completion of a criminal proceeding within a reasonable time (Section 14 of the CPL).

This issue is also highlighted in the Ministry of Justice Principles for Court Organization Development for the years 2009-2015, according to which the aim of the court organization policy is to sustain legality, efficiency and high-quality of the court system that has to comply with the needs of society, thus, facilitating the implementation of such fundamental judiciary values as independent and accessible courts and efficient conduct of trial proceedings within a reasonable time.

Amendments introduced to legislation, including the CPL, indicate that Latvian legislature considers it salient to respect the person's rights and observe the person's rights and freedoms, especially, the rights and freedoms identified in international documents.

The aim of this paper is to review the Convention and the CPL rights to completion of a criminal proceeding within a reasonable time in order to yield recommendations for a deeper comprehension of these rights and their more effective application.

The issue of the procedure to be held within a reasonable time has been analyzed in scientific articles of certain authors ${ }^{2}$. However, the extent to which the problem has been

of Human Rights. Round Table Organised by the Slovenian Chairmanship of the Committee of Ministers of the Council of Europe. Bled, Slovenia, 21-22 September, 2009, p.6. [interactive]. [accessed on 5-252013]. <http://www.coe.int/t/dghl/standardsetting/cddh/Publications/bledproceedings_book.pdf $>$.

2 Jurka, R. New Insights into the Procedure Within a Reasonable Time as a Legal Principle. Jurisprudencija. 2010, 1(119): 297-316; Kazaka, S. Kriminālprocesa Pabeigšana Saprātīgā Termiñā: Procesuālais 
investigated is rather narrow and there is still a lack of attention to the issues regarding this institute in criminal procedure.

The subject of the paper pertains to the norms of a criminal proceeding, rights and legal relationships developed on the basis of these norms and those associated with deployment of international standards that secure implementation of the person's rights to completion of a criminal proceeding within a reasonable time in real-life contexts.

Various research techniques of information acquisition, processing and a variety of contemporary research methods, both theoretical and empirical, such as the review and analysis of scientific literature, comparisons, the historical and logical method of inquiry, observations, etc., have been used.

\section{The meaning of the term reasonable}

However, prior to consideration of the impact of a reasonable time on the completion of a criminal proceeding, it is important to clarify the meaning of the term reasonableness. The Latvian language thesaurus dictionary provides the following definitions for the adjective reasonable: 1) The one having a reason: a reasonable being, a reasonable man. 2) The one capable of reasoning; the one pursued with the reason: reasonable thoughts, a reasonable decision; to judge/act reasonably. Besides, reason is the ability to think and judge adequately and creatively, a man of reason, an act of reason (to act reasonably), the voice of reason ${ }^{3}$.

The principle of reasonableness in a criminal proceeding is expressed as the necessity for subjects to remain within certain limits in order to exclude the malicious use of subjective legal rights, to ensure that their own actions comply with the protection of rights, freedoms and legitimate interests of persons involved in a criminal proceeding and to ensure that their own actions aim for the attainment of national and public goals.

In light of the fact that the term reasonable has traditionally been used also in the Anglo-American Law, it might be useful to consider the interpretation and application of this term as it is deployed in the Anglo-American legal tradition. The Anglo-American legal concept of a reasonable man is widely used and is defined as an ordinary citizen; however, occasionally this concept is also referred to as a bus man. In contrast to the concept of consciousness that characterizes human conscience by means

Aspekts. Administratī̄ā un Kriminālā Justīcija. 2011: 76-85; Meikališa, Ā. \& Strada-Rozenberga, K. Pārmainuu Laiks Kriminālprocesā Turpinās. Jurista Vārds. 2009, 26(579); Mits, M. European Convention on Human Rights in Latvia. Lund: Media Tryck, 2010. Štarienė, L. The Limits of the Use of Undercover Agents and the Right to a Fair Trial under Article 6(1) of the European Convention of Human Rights. Jurisprudencija. 2009, 3(117): 263-281; Trechsel, S. Human Rights in Criminal Proceedings. Oxford: Oxford University Press, 2005; Van Djik, P. Theory and Practice of the European Convention on Human Rights. Antwerpen, Oxford: Intersentia, 2006; Vitkauskas, D. \& Dikov, G. Protecting the Trial to a Fair Trial under the European Convention on Human Rights. Council of Europe. Strasbourg: 2012; Zappalà, S. Human Rights in International Criminal Proceedings. Oxford: Oxford University Press, 2005; etc.

3 Latviešu Valodas Skaidrojošā Vārdnīca. [interactive]. [accessed on 5-25-2013]. <http://www.latvianforyou.com/cgi-bin/l.pl?word=sapr\%C3\%A2t\%C3\%AEgs\&pos=583634>. 
of either burdening or non-burdening oneself with the information related to possible causation of harm to another person, the concept of reason characterizes the objective side of a person's action. Consideration of reasonableness of assessed activities includes the comparisons with the corresponding activities of an ordinary man. If the assessed activities of an indicated person are less useful or more harmful than those of reasonable man under identical circumstances, the reasonableness requirement is considered unfulfilled. Thus, the reasonableness is characterized by the person's intellectual and moral qualities and by indirect comparing of his or her conduct with the conduct of a possible ordinary man. A person shall act so that the negative consequences of his or her actions for another person can be minimized. The reasonableness limits are the actions that consider the interests of both the prosecution and defence fairly. The action that is less effective than reasonable is considered inappropriate ${ }^{4}$.

The term reasonableness is used in laws and regulations to identify the floating border between subjective rights and obligations for appropriate cases. The more general the description of an action related to the objective rights case is, the more pronounced is the necessity to apply the criterion of reasonableness to verify whether the action complies with the acceptable and appropriate pattern of behavior or not. S. Trechsel notes that 'the reasonable time is the time which will not be delayed's.

On top of all different standards governing the conduct of criminal proceedings in order to secure its fairness, a key consideration of the European Convention is that a person should be tried within a reasonable time. This obligation - which is extensively breached in practice - applies to both trial at first instance and the different levels of appeal. No particular period is prescribed as "reasonable" as the circumstances of cases inevitably differ. However, while complexity may explain some lengthy proceedings, inactivity in conducting them and delay as a result of inadequate resources are not acceptable excuses. Thus, the principle of reasonableness is based on the notion of social compromise between various legitimate interests ${ }^{6}$.

The observance of reasonable time that considers the influencing factors is similaraly explained within the system of the judicature of the European Court of Human Rights. A long practice of passing decisions on such types of violations has allowed to develop the criteria that help to understand the nature of the reasonable time concept as well as the cases when long duration is justifiable. Reasonability cannot be abstractly evaluated; however, one must evaluate the circumstances of each case individually ${ }^{7}$.

4 Regina $v$ Smith, 4 AER 289 The concept of the "reasonable man" has never been more than a way of explaining the law to a jury; an anthropomorphic image to convey to them, with a suitable degree of vividness, the legal principle that even under provocation, people must conform to an objective standard of behaviour that society is entitled to expect". 2000 [interactive]. [accessed on 5-25-2013]. $<$ http://www. publications.parliament.uk/pa/ld199900/ldjudgmt/jd000727/smith-1.htm>.

5 Trechsell, S. Human Rights in Criminal Proceedings. Oxford: Oxford University Press, 2005, p. 135.

6 McBride, J. Human Rights and Criminal Procedure. The Case Law of the European Court of Human Rights. Council of Europe Publishing, 2009, p.17.

7 Van Djik, P. Theory and Practice of the European Convention on Human Rights. Antwerpen, Oxford: Intersentia, 2006, p. 607. 
The simplest way to determine whether the reasonable time had been observed or not would be to introduce a fixed term; however, this approach might lead to injustice. ${ }^{8}$ Having considered the fact that unification of the duration would not be possible and would create room for a cycle of new violations, the author fully supports the abovementioned statement.

\section{Ways of protection of the right to a completion of criminal proceeding within a reasonable time}

The analysis of the European Court of Human Rights (hereinafter called the ECHR) activities demonstrates that the Court often examines cases of reasonable time violation applied to the conduct of a criminal proceeding and execution of the Court enforced decisions.

It is important to mention that the majority of the cases that are considered at the European Court of Human Rights against Latvia are directly connected to the violation of Part 1 of Section 6 of the European Convention on Human Rights, which refers to the rights to a fair trial. Overall, this Clause has been violated in 11 cases. In 8 cases the violation applied to the entire duration of a criminal procedure. In 7 cases the violation was directly connected to the unreasonably long duration of a trial. ${ }^{9}$ These facts point to initial drawbacks in the Latvian legal system that was not fully developed to secure a person's rights to the completion of a crimintal procedure within a reasonable time. One aspect of the already mentioned Lavents' case, which was the first case, was used to evaluate the then-Latvian Crimincal Procedure Code, which was regrettably found not satisfying the requirements. This case revealed both the drawbacks of the legal system and not always appropriate applications. The regulations of the Latvian Crimincal Code were improper to secure implementation of the standards of the European Court of Human Rights. Similar types of violations were detected in the cases of Kornakovs v. Latvia ${ }^{10}$ and Freimanis and Lìdums v. Latvia ${ }^{11}$, in which the Court recognized the violation of Section 6 of the Convention.

In order to comprehend tendencies in the fundamental human rights developments, it is important to follow the ECHR law cases and analyze the decisions passed with reference to other states. Such an analysis provides the grounds for timely evaluation and, if necessary, amendments of Latvian legal norms or their application.

The analysis of the Convention norms and their application affects the entire Latvian legal system. These norms and their application are also considered in the developments and adoption of new regulations that guarantee the observance of human rights in Latvia. The aim of the Convention is to provide persons with real rights, which states that rights

8 Trechsell, S. Human Rights in Criminal Proceedings. Oxford: Oxford University Press, 2006, p. 137.

9 Mits, M. European Convention on Human Rights in Latvia. Lund: Media Tryck, 2010.

10 Kornakovs v. Latvia. Nr. 61005/00.

11 Freimanis and Lìdums v. Latvia. Nr.73443/01 and Nr.74860/01. 
must have the material content, practical foundation and that they cannot be declared solely formally. Interpretations, conducted by the ECHR, cannot be overestimated; therefore, in order to fully observe the Convention requirements, the ECHR practices should be closely followed ${ }^{12}$.

The Convention specifies two main fair trial guarantee categories - organic and functional. The former guarantees are aimed at securing the conduct of fair trials, the implementation which is made plausible by obligation of public institutions to perform a specific set of duties, such as the establishment of legitimate trials, retainment of neutrality, publicity of the trial, etc. The aim of the latter guarantees is to secure the implementation of the equality principle throughout all stages of conduct of a criminal proceeding ${ }^{13}$.

The requirement for a fair trial mentioned in Section 6 of the Convention is among the functional guarantees. In the context of potential negative effects in a criminal proceeding, it becomes a mandatory requirement of paramount importance. Any person pursued in a criminal proceeding has the right to obtain a final decision on substantiate charge within a reasonable time.

Section 6 of the Convention in the field of criminal law highlights the requirement ensuring that defendants do not find themselves in an uncertain state while a decision on their substantiate charge has not yet been passed.

In such cases the state acquires a positive duty to ensure that all necessary measures (whether personnel- or financing-related) are taken so that the trial can proceed quickly. The entire public administration shall serve the interests of a timely fair trial.

The starting point of a trial (dies a quo) is the moment when a criminal case is initiated, It could be the date before a case is transferred to court, the arrest, the date of initiation of a criminal case, etc ${ }^{14}$. The concept of the initiation of a criminal case can be interpreted in a broad sense - it is a formal official statement, in accordance with which a person could have committed a criminal violation.

In such instances, one can establish parallels with Section 389 of the CPL terms for restriction of the person's rights in a pre-trial criminal proceeding. The two-way obligations are imposed on the terms for restriction: early.

1. Encourage the person directing the proceedings to complete a pre-trial proceeding

2. Provide a guarantee to the parties involved in a criminal proceeding that the restriction of their rights in a pre-trial proceeding will not be unreasonably long-term.

The term is specified for the entire pre-trial proceeding without distinguishing between the terms of investigation and prosecution. The division must be determined

12 Kazaka, S. Kriminālprocesuālā Aizturēšana un Tiesības uz Brīvību un Drošību. Kriminālprocesuālās Aizturēšanas Tiesiskums. Zinātniski Praktiskās Konferences Rakstu Krājums. Rīga: LPA, 2008, p. 30.

13 Kommentarij $k$ Konvencii o zashchite prav cheloveka i osnovnyh svobod i praktike ee primenenija. Pod redakciej V.A. Tumanova i L. M. Jentina. 2006 [interactive]. [accessed on 5-25-2013]. <http://www.hri. $\mathrm{ru} / \mathrm{docs} /$ ? content $=\mathrm{doc} \& \mathrm{id}=371>$. 
through cooperation between the investigator and the supervising prosecutor accompanied by the consideration of specific circumstances of a case.

When a person with the right to defence or a person whose rights to handle his or her property have been restricted by procedural actions is engaged in the case, a pre-trial proceeding must end or else all pre-trial proceeding measures and restrictions of rights related to the property must be suspended according to the following terms:

1. a criminal violation - within six months;

2. a less serious crime - within nine months;

3. a serious crime - within twelve months;

4. a particularly serious crime - within twenty two months.

In a criminal proceeding of a serious or particularly serious crime the investigating judge may extend the restriction of rights for the pre-trial proceeding by additional six months, however, no longer than by three months in one extension if the person directing the proceedings has not caused delays or else faster completion of the proceedings has not been possible due to a particular complexity of the case.

Describing the extension sequence of the term for restriction of the person's rights, it must be noted that the law provides for the extension of terms only for serious or particularly serious crimes. Therefore, it is impossible to extend the term for restriction of rights of a person accused of misdemeanor or a less serious crime. The exception applies when a person involved in a criminal proceeding is suspected or accused of a criminal offence, which involves a more serious crime committed by another person if his case is considered within the same criminal proceeding. Then, the investigating judge may extend the term for restriction of rights for this person pursuant to the involvement in the crime.

The investigating judge shall consider whether the person directing the proceedings has not caused delay or else faster completion of the proceedings has not been possible due to a particular complexity of the case. The maximum extension of the terms for restriction of the person's rights is six months, however, no longer than three months in one extension. This does not imply that the term may be extended only two times. The investigating judge has the right to extend the procedure by less than three months in one extension, e,g., by one month at one time, by two months next time and by three months yet the following time.

Assuming that the investigating judge has extended the procedure by the maximum term of six months, the total term for restriction of the person's rights cannot extend the period of 18 months for a serious crime and 28 months for a particularly serious crime.

When determining such terms for restriction of the person's rights, the legislature has presumed that this term would suffice for the majority of criminal proceedings. However, the terms for restriction of the person's rights must be specified to attain the following objectives: firstly, the terms shall be minimal to encourage the person directing the proceedings to complete the pre-trial proceeding faster. Secondly, these terms shall be sufficient for the person directing the proceedings to perform all required actions for the completion of the the pre-trial proceeding within specified terms. 
It is important to identify the onset of a pre-trial proceeding as a criminal proceeding stage and the onset of application of the terms for restriction of the person's rights (as the general rule of a pre-trial criminal proceeding). A pre-trial proceeding begins once the decision to initiate the criminal proceeding has been passed, a person who has the right to defence or a person whose right to handle his or her property have been restricted by procedural actions has been involved in the case and once the terms for restriction of the person's rights in the pre-trial proceeding have been specified.

The regulation of a specified term begins at the moment when a specific person whose constitutional and other rights have been restricted appears in a criminal proceeding. The criminal proceeding norms guarantee that the person's rights shall not be restricted for an unreasonably long term. As a guarantee that the investigator shall not involve persons with the right to defence or whose right to handle their property have been restricted in the proceeding for an unreasonable long term, the process is monitored by the supervising prosecutor ${ }^{15}$.

The CPL specifies persons who have the right to defence. In the pre-trial proceeding, most frequently this will be a person against whom the criminal proceeding has been initiated, a detainee, a person suspected or accused of a crime. There are usually no doubts about the moment when a detainee, a person suspected or accused of a crime, is entitled to defence because the acquisition of this status implies simultaneous entitlement to defence.

The case is different for a person against whom the criminal proceeding has been initiated. According to Section 61 of the CPL, if at the moment of the initiation of a criminal proceeding a specific person is suspected of a possible commitment of a criminal offence under investigation, the criminal proceeding shall be initiated against this person. The person shall acquire the status of a person against whom the criminal proceeding has been initiated once the decision to initiate the criminal proceeding has been passed. However, this person shall acquire procedural rights to defence from the moment he or she becomes involved in procedural actions or the information on the initiation of the criminal proceeding against him or her has been made public. Theoretically, the date of the initiation of the criminal proceeding might not coincide with the date when the person against whom the criminal proceeding has been initiated becomes involved in procedural actions or the information on the initiation of the criminal proceeding against him or her is made public. Consequently, the term for restriction of the person's rights will not take effect on the date when the criminal proceeding has been initiated, instead, it becomes effective on the date when the person has acquired the right to defence.

Section 389 of the CPL specifies that when the term for restriction of rights of a person has expired, the pre-trial proceeding shall be terminated or all security measures and restrictions of rights to property shall be suspended. If the pre-trial proceeding cannot be terminated within the specified term, all restrictions of rights shall be suspended. In

15 Meikališa, Ā.; Kazaka, S.; Lodīte, I. \& Petrova, S. Kriminālprocesuālie Termiņi Pirmstiesas Izmeklēšanā. Rīga: Petrovskis un Ko, 2006, p. 47. 
conclusion, in such cases the person shall not lose his or her status and shall retain the right to completion of a criminal proceeding within a reasonable time.

If Section 389 of the CPL specifies the terms for restriction of the person's rights in the pre-trial proceeding, these terms are not specified in court. In some cases, the law provides the commencement of adjudication of a criminal proceeding.

No later than within three working days of the receipt of the criminal case in the court proceedings, the judge shall pass a decision on the time and premises of the trial of a criminal case. The basic principle is that the adjudication of a criminal case shall commence as soon as possible. However, in certain cases the CPL provides specific terms for commencement of trials:

- The adjudication of a criminal case in agreement proceedings shall commence within 21 days from the day when the case was received in the court proceedings of a judge (Section 539/2 of the CPL).

- Upon the receipt of a criminal case that has been transferred to the court in accordance with the abridged procedure, the court shall initiate the trial thereof no earlier than in 10 days and no later than in 30 days (Section 488/6 of the CPL).

- The public prosecutor shall determine the term for the trial by coordinating the term with the court, yet the duration of the term prior to the court session shall not be shorter than 3 or longer than 10 working days, counting from the day when the accused was issued a copy of the decision. The prosecutor shall send a summons to all parties summoned to the court session (Section 427/2 of the CPL).

- If a security measure relates to holding an accused in custody, the adjudication of a criminal case shall commence no later than within 4 weeks of the receipt thereof (Section 488/3 of the CPL).

- If a security measure relates to holding an accused, who is a minor in custody, the adjudication of a criminal case shall commence no later than within 3 weeks of the receipt thereof (Section 488/4 of the CPL).

In a case when a security measure, applied to an accused, relates to his or her holding in custody and compliance with the set terms is impossible due to objective reasons, according to the $\mathrm{CPL}$, the judge can set the commencement of the trial for a later date, grounding his or her action in a reasoned decision.

As it has been already mentioned, the length of adjudication in the CPL is not regulated. The analysis of statistical data can be used for drawing conclusions on specific tendencies.

According to statistics on the length of criminal proceedings in Latvian courts of first instance, during the year $2012^{16}$ five thousand two hundred eighty two criminal cases $(55.5 \%)$ were examined within 3 months. During the same year, 1573 cases $(16.5 \%)$

16 Statistikas Pārskats par Krimināllietu Izskatīšanas Ilgumu Pirmajā Instancē Latvijas Tiesās 2012. Gadā. 2012 [interactive]. [accessed on 5-25-2013]. <http://www.ta.gov.lv/UserFiles/1366962720_Krim_ ilg_1i_2012.pdf>. 
were examined within 3-6 months. Overall, 87\% of criminal cases were examined in the first instance courts that year, which is considered to be a positive indicator.

However, it must also be noted that the examination of 240 cases $(2.5 \%)$ in the first instance courts took 36 months or longer. Sixty-nine cases were related to theft (Section 175 of the CL) and theft, fraud and misappropriation on a small scale (Section 180 of the CL).

The statistics demonstrate that the terms for examination of criminal cases have slightly increased.

However, the duration of examination of $1383(76,2 \%)$ criminal cases during the year $2012^{17}$ in district appeal courts constituted 3 months and the duration of examination of $270(14,9 \%)$ criminal cases was 3-6 months.

The total number of cases examined during the period of one year in 2012 in district appeal courts was $97.4 \%$. It can be concluded that in comparison to 2009 , in 2011 , the appeal court criminal cases were examined for a slightly longer period, since in 2009 , $98.8 \%$ cases were examined. It must be mentioned that the examination of 3 criminal cases in appeal courts took 24-30 months, which, however, may cast some doubts on compliance with a reasonable time term.

The experience of the ECHR demonstrates that there are specific criminal proceedings that require particularly fast examination, e.g., the cases that require consideration of the risks that the accused might incur.

As an example, a case of $X$. v. France (1992) could be introduced. In the case of $X$. v. France the applicant, who was suffering from hemophilia, died a month prior to the commencement of the trial. He underwent several blood transfusions and contracted the HIV infection from contaminated blood transfusions. X submitted compensation claims to court, requiring public institutions to compensate his suffering. Adjudication of the criminal case lasted for more than two years. The decision of the ECHR was such that despite the fact that the government had not caused unjustified delay, the ECHR had to act extremely cautiously because the potential lifespan of the applicant could be significantly reduced due to his illness. The ECHR highlighted that the state authorities did not use all measures available to them to speed up the trial and thus acknowledged the violation of Section 6 of the Convention. Similar developments were observed in the case of Martin Moreira v. Portugal (1988), in which the applicant had suffered serious injuries in a car accident. He sued the man who was responsible for the accident. The ECHR decision in this case, as well as in the case mentioned above, was to approach the trial on compensation for a victim, whose injuries resulted from a car accident, with caution. The court identified violations in the case trial based on unjustified delays of authorities.

According to Section 14 of the CPL, the person directing the proceedings shall select the simplest type of a criminal proceeding that complies with the specific conditions of the case and shall allow neither for unjustified intervention into the life of the person

17 Statistikas Pārskats par Krimināllietu Izskatǐšanas Ilgumu Pirmajā Instancē Latvijas Tiesās 2012. Gadā. 2012 [interactive]. [accessed on 5-25-2013]. <http://www.ta.gov.lv/UserFiles/1366962720_Krim_ ilg_1i_2012.pdf $>$. 
nor for unfounded expenditures. The law specifies three types of criminal proceedings that shall have prevalence over other criminal proceedings in securing implementation of the reasonable time framework. These criminal proceedings are the following ones:

1. criminal proceedings wherein a security measure relating to taking an accused into custody applies;

2. criminal proceedings involving a person who receives special procedural protection;

3. criminal proceedings against a minor that have prevalence over similar criminal proceedings against a person of legal age when securing the application of a reasonable term.

There is a special group of persons who are held in custody during the proceedings. The imperative requirement of Section 5 of the Convention emphasizes the following points: presumption of innocence, the point according to which the liberty of an accused shall not be restricted for longer than it is necessary and the point in accord with which the liberty restrictions shall be lifted if imposed unjustifiably. Thus, the persons who have restricted the liberty of others have the responsibility to prove not only the fact that their actions were in accord with Section 5 of the Convention, but also that their powers could be applied in the specific context. ${ }^{18}$

To reduce the terms of criminal proceedings, the legislature has offered the differentiation of proceeding types, allowing the person directing criminal proceedings to select one type from the so-called simplified types of criminal proceedings. The person directing the proceedings shall select the simplest type of a criminal proceeding that complies with concrete conditions and shall not allow for unjustified intervention into the life of a person and unfounded expenditures. To speed up the completion of the pre-trial proceeding, the supervising prosecutor shall provide instructions on the selection of a proceedings type, direction of investigation and investigative activities if the person directing the process does not provide the targeted investigation and allows for delays or unjustified intervention into the life of a person.

The development of the criminal law pertinent to the trial acceleration and resource economy represents a characteristic tendency not only for Latvia, but also for the entire Europe and other parts of the world.

Recommendation Nr. R (87) 18 of the Committee of Ministers of the Council of Europe on The Simplification of Criminal Justice specifies that delays in the administration of criminal justice might be remedied not only by the allocation of specific resources and the manner in which these resources are used, but also by a clearer definition of priorities for the conduct of crime policy with regard to both form and substance by the simplification of ordinary judicial procedure, the so-called simplified procedures, outof-court settlements by authorities competent in criminal matters and other intervening authorities, as a possible alternative to prosecution.

Professor S. Osipova has yielded an interesting idea. Specifically, the Latvian legislation does not provide a mechanism to eliminate obviously unjustified legal 
actions. Persons are provided with extensive rights to sue in court; however, frequently these rights are used merely for the sake of the process. Currently, minor cases are also examined in all three court instances, which results in the enormous waste of resources and useless overload of courts. In order to guarantee freedom and security to a person, it is essential to ensure the harmonious functioning of society and timely, lawful and fair settlement of jurisdictional conflicts. However, the implementation of the rights of certain persons should not threaten other persons. Legal actions aim to guarantee freedom to a person, however, this does not entail that the guarantee of freedom and legitimate rights to a person should contradict public interests. Human rights to a fair trial as well as other fundamental rights are not absolute as the German Federal Constitutional Court noted yet in the second half of last century. (...) Therefore, it can also be useful for Latvia to establish reasonable limits of the person's rights to a fair trial by balancing these limits with public interests so that unreasonable conflicts of certain persons do not unnecessarily waste common resource of society ${ }^{19}$.

The duration of adjudication is found significantly reduced when the examination of evidence during the trial is not conducted. According to the Increasing of Independence and Effectiveness of Jurisdiction and Strengthening the Reserves report, $80 \%$ of criminal cases have been adjudicated without examination of evidence ${ }^{20}$.

\section{Criteria for completion of criminal proceedings within a reasonable time}

The end of a criminal proceeding (dies ad quem) is frequently interconnected with the entry into force of the final adjudication. What amounts to a reasonable time depends on the circumstances of the case ${ }^{21}$. According to the general rule, a reasonable time is specified by assessing particular conditions of the case and considering the following criteria: the complexity of the case, behavior of the accused and behavior of the competent authorities.

The decision passed on January 11, 2007 of the Department of Criminal Cases of the Senate of the Supreme Court of the Republic in the case SKK - 15/2007 specifies similar aspects, emphasizing that the completion of a criminal proceeding within a reasonable time is linked to the scope of the case, legal complexity, amount of procedural activities, attitude to the fulfillment of duties of the persons involved in the process and other objectives conditions ${ }^{22}$.

19 Osipova, S. Ievads Tiesību Sociologijāa. Rīga: Tiesu Namu Ag̉entūra, 2010, p. 111.

20 Tiesu Varas Neatkarības un Efektivitātes Palielināšanas un Nostiprināšanas Rezerves. 2010 [interactive]. [accessed on 5-25-2013]. <http://www.juristavards.lv/?menu=doc\&id=206150>.

21 Foster, S. Human Rights and Civil Liberties. Great Britain: Pearson Education, 2008, p. 227.

22 Latvijas Republikas Augstākās Tiesas Senāta Krimināllietu Departamenta 2007. gada 11. Janvāra Lēmums Lietā SKK -15/2007. 2007 [interactive]. [accessed on 5-25-2013] <www.at.gov.lv/files/archive/ department2/2007/kd110107.doc>. 
This explanation is also specified at the normative legal level in Section 14, paragraph 1 of the CPL, i.e., the completion of a criminal proceeding within a reasonable time is linked to the scope of the case, legal complexity, amount of procedural activities, attitude to the fulfillment of duties of the persons involved in the process and other objectives conditions.

A reasonable time is a "filling" concept, and "the reasonability" is evaluated within the framework of each particular case. At the same time, the overall criteria which along with amendments are included into the Criminal Procedure Law, identification and further inclusion of the indication "and other circumstances" do not really create the violation of the the term's specificity. Appropriate explanations could be included into comments, scientific research, monographs, practice guidelines, etc. On such grounds, amendment to the law would not be required.

According to Section 1, part 1, paragraph 4 of the CPL, the inobservance of a reasonable time might lead to termination of a criminal proceeding resulting in the release of the accused from the criminal liability. This regulation is applied to the pre-trial proceeding that is directed by an appropriate institution as well as court. Consequently, it is important to understand the key factors that affect proper compliance of procedure with a reasonable time, i.e., without any unjustified delay. These terms cannot be determined ideally and only in connection with particular conditions of a case.

The content of these aspects has been also revealed by the ECHR in a number of cases v. Latvia, e.g., Lavents c. Lettonie (2003) Nr.58442/00, Kornakovs v Latvia (2006) Nr. 61005/00, Freimanis and Lidums v Latva (2006) Nr.73443/01 un Nr.74860/01, etc.

The first issue to assess is the legal complexity. All aspects of complexity factors are important. This complexity may be related to actual issues as well as legal aspects, such as the characteristic features of the fact that has to be examined, the number of the accused and victims, international factors, connection of the case to other cases, involvement of new persons in the process, the record of a large amount of episodes in accusation (Vaivada v. Lithuania, 2005) or a large number of defendants in a case (Meilus v. Lithuania, 2004). ${ }^{23}$ The issue could also be assessed from the angle of the legal complexity of court proceedings, e.g., with consideration of recent regulations entered into force (Pretto and others v. Italy, 1983).

Occasionally, the significant legal complexity may serve as the basis for a longterm trial, e.g., in the case of Boddaert v. Belgium (1992) the ECHR did not found 6 years and 3 months as unjustifiably long-term court trial as it was a complex murder case and 2 other cases were found related to this case.

However, even aggravated cases might result in unjustified delays, such as in Ferrantelli and Santangelo v Belgium (1992). The ECHR claimed that the criminal proceedings of this case, which had been in progress for over 16 years, were incommensurable, even despite the complex and sophisticated nature of the case. ${ }^{24}$

23 Vitkauskas, D. \& Dikov, G. Protecting the Trial to a Fair Trial under the European Convention on Human Rights. Council of Europe. Strasbourg: 2012, p. 75.

24 Evropejskaja konvencija o zashchite prav cheloveka i osnovnyh svobod. Statja 6. Pravo na spravedlivoe sudebnoe razbiratelstvo. Moskva: Rossijskaja akademija pravosudija. 2001 [interactive]. [accessed on 5-21-2013]. <www.the ECHR.ru/documents/manuals/Article06/Article6.rtf.>. 
Such violations, especially the violations of Section 6 paragraph 1 of the Convention, have been reported by the ECHR to have taken place in Latvia, too. One such case was the case of Eduards Kornakovs v. Latvia ${ }^{25}$. In July of 1996 the police initiated the criminal proceedings against him for robbery with the use of violence. On September 11, 1996 E. Kornakovs (an applicant) was recognized as a suspect for this crime; he was detained and kept on detention premises. On September 13, 1996 the prosecutor's office accused him of this robbery. On the same day he appeared before the judge of the district court of Latgale, who used the arrest as a security measure. Subsequently, the court extended the application of this security measure. On June 20, 1997 the prosecutor's office announced the termination of the pre-trial proceedings and obliged to submit examination materials to other applicants, 14 persons accused in the same criminal case, and their defence counsels.

On September 4, 1998 the prosecutor's office prepared the final adjudication against the applicant and on September 7, 1998 the case was transferred to the district court of Riga. Some delays in the conduct of the trial followed; however, on September 24-25, 2001 the district court of Riga announced the adjudication in public hearing and recognized the applicant as being guilty on all counts of violations incriminated to him; he was sentenced to 10-year and 1-month imprisonment.

On December 10, 2001 the applicant appealed against the procedural decision to the Chamber of Criminal Case of the Supreme Court. The decision of the Chamber of Criminal Case, issued on January 17, 2003, re-qualified the accusation of the applicant and reduced the imprisonment term to 8 years and 1 month. On June 2, 2003 the applicant submitted a cassation complaint to the Senate of the Supreme Court. On August 6, 2003 the Senate rejected the complaint.

On September 8, 2004 the applicant submitted the complaint to the ECHR in which he complained about several counts of violation of conduct of the pre-trial proceeding and the adjudication of the case by Latvian institutions. On October 21, 2004 the ECHR acknowledged the receipt of the complaint and accepted the case for further examination.

Despite the complexity of the case and several force majeure circumstances, the ECHR claimed that the criminal proceedings lasted for the unreasonably long term and unanimously agreed on the violation of Section 6 paragraph 1 of the Convention, i.e., on unjustified delays (involving the period of time between the submission of the case to court and commencement of the court trial, duration of intervals between hearings) in criminal proceedings. Similar violations have been identified in the case of Olegs Moisejevs v. Latvia.

When deciding about the compliance to a reasonable time, it is important to consider the attitude towards the fulfillment of their duties by the persons involved in process. This attitude might be expressed through the submission of numerous complaints and applications, requests for extension of the term of adjudication, frequent submission of recusation applications, etc. When considering the issue, it shall be noted that the persons who have the right to defence do not have the obligation to actively 
cooperate with the persons directing the criminal proceedings. Therefore, these persons could not be blamed for exploiting their right to defence as identified in national legal acts. However, their behavior should be regarded as an objective factor for which the respondent states cannot be blamed and this should be considered when assessing violations described in Section 6 of the Convention.

In the case of Ciricosta and Viola v. Italy (1955) the ECHR determined that a 15 -year-long proceeding could not be regarded as incommensurable because the applicant requested the court to delay his hearings at least on 17 occasions and the opposite party expressed similar requests on 6 various occasions. ${ }^{26}$

It must be emphasized that determination to speed up examination of the case does not free officials from the liability for the case progress when applying measures to ascertain justified or unjustified accusation. Section 6 of the Convention does not require an active cooperation of the accused with courts.

Furthermore, it is important to consider the fact that when any participant of the case causes delay in the proceedings, the state cannot be directly held responsible for this. Nevertheless, some questions might arise: has the state conducted all necessary measures to facilitate faster developments in the proceedings? Has it not delayed the trial for a significantly longer term without any justified reason? Under all circumstances, however, the state has the duty to ensure the progress of the proceedings within a reasonable time. Thus, for instance, when a trial must be delayed, it is salient to set a new trial date to minimize the delay.

The ECHR considers the legal complexity and the attitude to the fulfillment of their duties by persons involved in the process in instances when the state has conducted all necessary and effective measures to enhance the present condition. Therefore, the key factor that is assessed by the ECHR in cases pertaining to observance of a reasonable time in criminal proceedings is the conduct of competent authorities.

The state is held responsible for the delays that have occurred as the result of administrative or court actions. The most typical delays caused by the state relate to transfer of criminal cases to other premises, announcement of the adjudication to the accused and preparation and adjudication of cases in appeal courts. Some other typical delays occur in cases that examine accusation of two or more persons simultaneously.

The case of B. v. Austria (1990) related to the serious fraud, which resulted into the ECHR announcing acceptable the duration of 2.5 years that were required to complete the criminal proceedings and yield adjudication. At the same time, however, the violation of Section 6 of the Convention was ascertained because the judge required 33 months to complete adjudication and without it the appeal would not have been possible.

In the case of Zimmermann and Steiner v. Switzerland (1983) the ECHR indicated that states had the duty to "organize their systems of rights in the way that it would be possible to act in compliance with the requirements of Section 6, ensuring the trial within a reasonable time". The ECHR emphasized that the reason for delay was the overload

26 Evropejskaja konvencija o zashchite prav cheloveka i osnovnyh svobod. Statja 6. Pravo na spravedlivoe sudebnoe razbiratelstvo. Moskva: Rossijskaja akademija pravosudija. 2001 [interactive]. [accessed on 5-21-2013]. <www.the ECHR.ru/documents/manuals/Article06/Article6.rtf.>. 
of courts, the consequence of which was the violation of Section 6 of the ECHR as the state did not apply any measures to ameliorate the conditions. Adequate measures could have been the assignment of additional judges or administrative members to handle the cases. The violation would not have been ascertained if a delay happened to have been merely a temporary or exceptional instance and if the state had deployed all necessary measures to enhance the conditions. Overall, the ECHR considers political and social aspects prevailing in given circumstances in a certain state when passing its decisions.

The case of Eckle v. Germany (1982) is an interesting one because the complete or partial refusal of criminal prosecution was considered with relation to the reasonable time term. The case applicants pointed to unjustified delays in the proceedings on the grounds that the investigation into a large number of violation episodes related to the case had been conducted. The German government claimed it had acted responsibly and in compliance with the principles of duties that required investigating all cases of violation committed by the accused. It was due to this case, especially to its submission to the ECHR, that amendments to legal acts allowing for the complete or partial refusal of the criminal prosecution on the grounds of violation of the conditions of the reasonable time term were introduced. The court ascertained that indeed a large number of episodes could not but had an effect on the terms of the pre-trial proceeding and that the state could not draw upon drawbacks of national legal acts when facing the obligation to fulfill its duties specified in the Convention. Thus, the German government and the ECHR indirectly acknowledged that the legal acts were incomplete because they did not provide for the termination of the criminal proceeding if it could not be completed within a reasonable time.

In Latvia the norm that enabled termination of a criminal proceeding due to inobservance of a reasonable term originally was mentioned only in Section 14 paragraph 5 of the CPL with reference to the sequence specified by the CPL. The special section of the CPL did not envisage this sequence. However, to secure observance of human rights, it is essential to have a mechanism enabling a person to restore his or her rights that have been infringed.

In its decision on the case Lavents v. Latvia the European Court of Human Rights mentioned that typically the use of all legal procedural means cannot be used against an applicant on the grounds that this delays the trial: the state must organize the court procedure in such a way that in case a participant of the trial uses all procedural means available to his/her disposal, this still leads to the completion of the court procedure within a reasonable time. ${ }^{27}$

The Court acknowledged the fact that the case was an extremely complex one and noted that substantial delays had been caused by the applicant's state of health, but held that the applicant could not be held responsible for such delays as they had been the result of force majeure. What regards the conduct of the national authorities, the Court observed that 10 months and 28 days had elapsed between the date on which the judges

27 Decision of the European Court of Human Rights of 28 November 2002 in the Case of Lavents v. Latvia (Lavents c. Lettonie) // "LV", 12 February 2003, Nr.23. 
had withdrawn from considering the case, citing Government pressure, and the date on which the case had been referred to a different bench, without any reason having been given for such inaction. Therefore, the Court concluded that the judicial authorities had not shown the diligence required for the proper conduct of proceedings, and held that there had been a violation of Article 6 paragraph 1 of the Convention.

The ECHR emphasizes that effective remedy implies implementation of actions that are directed at elimination of violations, thus, guaranteeing the right to complete a criminal proceeding within a reasonable term (Burdov v. the Russian Federation).

If such a mechanism does not exist, the catalogue of human rights provided in international and national documents does not have a real basis; then the catalogue is declaratory and is not complied with. Therefore, in case of violation hardly any adequate response can be expected from law enforcement institutions. Thus, it is essential to develop a mechanism, entrenched in law or other legal acts, enforcing the deployment of this catalogue and specifying the necessity to have specially trained persons who can be held responsible for the implementation of points specified in the catalogue.

Considering the abovementioned statement, amendments have been made to Section 379 paragraph 1; more specifically, Clause 4 has been added, which envisages the termination of a criminal proceeding, releasing a person from criminal liability if the criminal proceeding cannot be completed within a reasonable time.

This norm refers to the pre-trial proceeding, court procedures, providing the possibility to terminate a criminal proceeding in case of violation of a reasonable time for every person directing the proceeding (for the investigator with the permission of the supervising prosecutor). However, this procedure can apply only if a person against whom the criminal proceeding has been initiated agrees with the action. This procedure is introduced to secure the rights of the accused in accordance with Section 380 of the $\mathrm{CPL}$, which states that the termination of a criminal proceeding, releasing a person from a criminal liability, is a non-exonerating condition.

It might be possible that the existence of this norm in the CPL encourages the persons directing the process to more thoroughly analyze both the implementation of the process and final adjudications. However, it should be noted that when evaluating a reasonable time, reference to such issues as court overload, lack of employees and financing, etc., the issues that are topical for Latvia, cannot be made as the ECHR does not accept them as an excuse.

Despite the fact that the CPL provides the principle of duties that imposes duties on officials who are competent to lead the criminal proceedings and who have the capacity and authority to initiate a criminal proceeding and settle it in accordance with the fair settlement of criminal relations provided in the CL, it is essential to consider the right to the completion of a criminal proceeding within a reasonable time. A fair settlement of criminal relations cannot be attained by ignoring the person's rights to completion of a criminal proceeding within a reasonable time and justifying this ignorance by the necessity to attend to other seemingly more important duties. 
In 2012 the Highest Court of the Republic of Latvia conducted research ${ }^{28}$ that analyzed the decisions of the Senate passed from 1 January, 2011 to 17 August, 2012. Overall, 56 decisions of the Criminal Case Department that referred to the judicature of the European Convention on Human Rights or Court were identified. The greatest number of references was to Section 6 of the European Convention on Human Rights, which is the rights to a fair trial -47 out of 56 decisions made a reference either to the judicature of the European Convention on Human Rights or the European Court of Human Rights. The second most frequently referred to clause was Section 3 of the European Convention on Human Rights, which stands for the ban on torture (5 decisions). Section 7 of the same Convention - inadmissibility of punishment without the appropriate law - was mentioned in 4 decisions.

One of these decisions, especially Senate's Decision Nr. SKK-95/2012 of the Highest Court of 13 March 2012, identified the European Convention on Human Rights as a substance having the function of an interpretation tool. A defendant complained about the long duration of a trial, providing a reference to Section 14 of the Criminal Procedure Law, Section 92 of the Constitution and Section 6 of the European Convention on Human Rights. ${ }^{29}$ Having referred to the ombudsman's statement and the decision of the European Court of Human Rights in the case of Deweer v. Belgium, the Criminal Case Department of the Senate of the Highest Court initially announced that under Section 6 of the European Convention on Human Rights the moment from which to consider the onset of the duration of a tiral was to be the investigation stage in the precourt procedure (the author's note: in specific cases the Crimincal Case Department interpreted these rights as applicable only to the pre-court stage ${ }^{30}$. This might create a concern that the norms of the European Convention on Human Rights might be used inappropriately and this might have a significant impact on the outcome of the case). In this case, time periods that were subject to state actions were identified, including instances of application of excessive duration due to the appeal court actions. The European Court of Human Rights in its decisions pointed to the criteria that had to be used to evaluate the duration of a trial: the complexity of a case, individual's and the officials' actions and concerned interests. Finally, without specifying legal norms, whose violation was announced, it was concluded that violation of the right to the case completion within a reasonable time had occurred. However, prior to conducting the analysis, the Criminal Case Department pointed to the violation of Section 14 of the Criminal Procedure Law. In addition, considering the violation to the specified fair trial, the Criminal Case Department applied the conditions on sentence reduction of Section $49^{1}$ of the Criminal Law.

28 Eiropas Cilvēktiesību Tiesas Judikatūra Latvijas Republikas Augstākās Tiesas Nolēmumos. Latvijas Republikas Augstākās tiesas Pētījums. Rìga: 2012. (Research of the Highest Court of the Republic of Latvia on the Effect of the Judicature of the European Court of Human Rights on the Decisions of the Highest Court of the Republic of Latvia. Riga: 2012)

29 Senate's Decision of the Highest Court Nr. SKK-95/2012 of 13 March, 2012.

30 Senate's Decision of the Highest Court Nr.SKK-5/11 of 5 March, 2011. 
The previously considered decision of the Criminal Case Department provided an answer to the question of violation of the European Convention on Human Rights. At the same time, many decisions either confirming or denying the violation of the European Convention on Human Rights were identified, however, the justification was not provided.

The right to a fair trial within a reasonable time implies not only that several measures are taken aimed at reducing the length of proceedings. Since it is not only the principle of "justice delayed is justice denied", one must also avoid a situation where "justice hurried, justice is buried". In other words, for proper judicial proceedings a balance between "efficiency" and "quality" 31 is necessary.

The new direction of the ECHR actions is related to a specified principle claimed in the case of Kudla v. Poland (2000), according to which a national court has the duty to provide a separate procedure that would be an effective remedy for the protection of rights of a person who has submitted a complaint about an extremely long-term hearing procedure. In turn, inability to ensure the legal protection of these rights at the national level will be regarded as the violation of Section 13 of the Convention that envisages the provision of the rights for effective legal remedy.

In cases when the state has introduced such a procedure, the sums for damage compensation related to the infringement of the right to completion of a criminal proceeding within a reasonable time must correspond to the compensation sums for similar cases specified in the ECHR.

Admittedly, the Latvian legislation contains the norms allowing the assessment of the compliance with the right to completion of a criminal proceeding within a reasonable time when determining the sentence (Section $49^{1}$ of the Criminal Law).

If a court decides that the person's rights to completion of a criminal proceeding within a reasonable time have been infringed, it can introduce the following actions:

1) Consideration of the infringement of these rights and imposition of a lesser form of sentence when determining the sentence.

2) Imposition of a sentence that is below the minimum limit sentence for such and similar crimes, as it is identified by Law.

3) Imposition of another, lesser form of sentence that is typically imposed for similar crimes, as it is identified by Law.

If a court considers that the person's rights to completion of a criminal proceeding within a reasonable time have been infringed and a person has committed a crime for which the death penalty or life imprisonment may be imposed, as it is specified in Section Sentence in the Criminal Law, the court shall substitute the death penalty or life imprisonment with the sentence of deprivation of liberty for twenty years.

At present, it is difficult to judge the effectiveness of the norms provided in Section 379 of the CPL and Section $49^{1}$ of the Criminal Law since these norms have entered into

31 Pim, A. The right to Trial within a Reasonable Time and Short-Term Reform of the European Court of Human Rights. Round Table Organised by the Slovenian Chairmanship of the Committee of Ministers of the Council of Europe. Bled, Slovenia, 21-22 September 2009, p. 26 [interactive]. [accessed on 5-252013]. <http://www.coe.int/t/dghl/standardsetting/cddh/Publications/bledproceedings_book.pdf>. 
force recently. However, it should be noted that the basis for the effective guarantee of the right to completion of a criminal proceeding within a reasonable time is the appropriate legal regulation and real application of this regulation. Hopefully, amendments in legal acts will encourage competent officials to apply measures guaranteeing the application of the person's rights to completion of a criminal proceeding within a reasonable time.

In 2010 Mits wrote that the reason for a significant number of complaints submitted to the European Court of Human Rights regarding the unreasonably long duration of a criminal procedure in Latvia lies in the lack of local legal protection remedies. ${ }^{32}$ According to Mits, the situation related to this clause of the Criminal Law that eventually might result in a person's only remaining option of submitting a case to the European Court of Human Rights has been changing. Specifically, a person whose rights in this regard have been violated will be provided with an access to a mechanism securing the use of legal protection means at the national level.

This presupposition is consistent with the position of the European Court of Human Rights, which at the end of 2012 declined Andris Trupa's (the applicant) complaint about the unreasonably long duration of the criminal procedure, encompassing the period of then-applicable Criminal Procedure Law. According to the applicant, the case consideration period of 6 years and 8 months that took place in 3 different courts was the violation of his right to the case completion within a reasonable time guaranteed by the European Court of Human Rights and Point 1 of Section 6 of the Convention for Protection of Basic Freedoms. At the same time, the Court recognized that in fact the submitted complaint could not be accepted for further review because the complaint's applicant had not exhausted the opportunities for protection of rights provided by Section 14 of the Criminal Procedure $\mathrm{Law}^{33}$.

The Court reminded that it had already considered similar complaints from Latvia and on numerous occasions had previously criticized the state for the lack of means for protection of rights. It also pointed out the fact that the Latvian Criminal Procedure Law which had applied prior to 1 October 2005 did not offer persons effective means for protection of rights in cases of an unreasonably long duration of a criminal procedure. However, having evaluated the applicant's complaint in this case, the Court supported the government's decision, in accordance with which since the application of the Criminal Procedure Law of 1 October 2005 the legal situation had changed in Latvia because Section 14 of the Criminal Procedure Law secured the rights to the completion of a criminal procedure within a reasonable time and in case of violation of these rights, courts could either terminate a criminal procedure or could reduce the sentence in compliance with the 2009 and 2012 amendments.

\section{Conclusions}

Since passing the Criminal Procedure Law in 2005 a complicated transition process aiming at the amendment of the procedural order with a particular emphasis

32 Mits M, European Convention on Human Rights in Latvia, Lund: Media Tryck, 2010.

33 Trüps v. Latvia. Nr. 58497/08 
on the standard observance of human rights has been completed. Thanks to the recent amendments of the Criminal Procedure Law, the normative regulation provided in the Crimincal Law and pertaining to the observance of a reasonable time is no longer only a stated right. In fact, it applies to real-life cases and functions as the rights' security tool that allows for those who are in charge of a trial to absolve a person from criminal liability if it is impossible to secure the completion of a crimincal procedure within a reasonable time. It is possible to ascert that formally the regulation ascerted in legal acts complies with the recognized requirements of the European Court of Human Rights. Regarding this issue, both procedural and material norms have been coordinated and under their effective implementation the number of instances of violation of rights related to the observance of the right to having a case considered within the reasonable time would have to be reduced.

After the study conducted, the author was able to draw the main conclusions, which are as follows:

1. The rights to the completion of a criminal procedure constitute an essential basic criminal procedure principle that is regulated by international human rights acts.

2. Any person, who is suspected of a crime or is accused of a crime and against whom a criminal procedure has been initiated, has the right to the completion of a criminal procedure within a reasonable time. Abstractly evaluating the issue, the rights to the timely completion of a case have to be possessed by any person when the justified presumption that the criminal prosecution of him/her will be started appears.

3. The observance of a reasonable time is connected not only with the specific time period within which a trial must be completed, but also with actions of persons in charge of the trial without justified delay. It is impotant to evaluate whether the officials involved in the trial have done everything in their power to complete the trial rapidly and effectively or not. It is possible to state that the reasonability is evaluated through the prism of a category of an attitude rather than time.

4. The completion of a case within a reasonable time has been affected by various factors; however, neither the case complexity nor persons' attitude to the fulfillment of their duties can be used as justification for the actions of the responsible state institutions that are not aimed at the timely completion of a case.

5. When applying the norms of the European Convention on Human Rights, it is important to remember that not always it is sufficient to limit oneself to the literal interpretation of the European Convention on Human Rights. It is also important to conduct a deeper analysis of the text in order to determine which of the standards of the European Convention on Human Rights is applicable in a particular situation. Both the judicature of the European Court of Human Rights and legal scientific works are used as assistance tools.

6. In the Latvian legal system, significant changes have been implemented in the domain that guarantees the observance of human rights. Currently, national legal acts make provisions for specific actions in cases when the right to the completion of a criminal procedure within a reasonable time is not observed. In compliance with Part 4 of Section 379 of Criminal Procedure Law and Part 4 of Section 58 of Criminal Law, 
a trial can be completed and a person might be absolved of criminal liability based on the fact that a criminal procedure cannot be completed within a reasonable time. At the same time, Section 49.1 of the Criminal Law provides legal protection tools in cases when persons' rights to the completion of a trial within a reasonable time have already been violated.

7. It is important to remember that the judicature and the rights' doctrine in the domain of human rights is still continuing to form in Latvia. The judicature of the European Court of Human Rights can help determine the content of the national legal norms and methodology of application in complicated situations.

\section{References}

Constitution of the Republic of Latvia. Latvijas Vèstnesis. 1993, 43 [interactive]. <http:// www.humanrights.lv/doc/latlik/satver 1. htm>.

Criminal Law. Latvijas Vēstnesis. 1998, 199/200 (1260/1261) [interactive]. <http://www. likumi.lv/doc.php?id=88966\#saist_11>.

Criminal Procedure Law. Latvijas Vēstnesis. 2005, 74 (3232) [interactive]. <http://www. likumi.lv/doc.php?id=107820\#saist_11>.

Eiropas Cilvēktiesību Tiesas Judikatūra Latvijas Republikas Augstākās Tiesas Nolēmumos. Latvijas Republikas Augstākās Tiesas Pêtījums. Rīga: 2012. (Research of the Highest Court of the Republic of Latvia on the Effect of the Judicature of the European Court of Human Rights on the Decisions of the Highest Court of the Republic of Latvia. Riga: 2012).

European Convention for the Protection of Human Rights and Fundamental Freedoms. 1950.

Foster, S. Human Rights and Civil Liberties. Great Britain: Pearson Education, 2008, p. 227.

Jurka, R. New Insights into the Procedure Within a Reasonable Time as a Legal Principle. Jurisprudencija. 2010, 1(119): 297-316.

Kazaka, S. Kriminālprocesa Pabeigšana Saprātīgā Termiṇā: Procesuālais Aspekts. Administratīvā un Kriminālā Justīcija. 2011: 76-85.
Kazaka, S. Kriminālprocesuālā Aizturēšana un Tiesības uz Brīvību un Drošību. Kriminālprocesuālās Aizturēšanas Tiesiskums. Zinātniski Praktiskās Konferences Rakstu Krājums. Rīga: LPA, 2008, p. 30.

Kornakovs v. Latvia Case, No. 61005/00, 2006.

Latviešu Valodas Skaidrojošā Vārdnīca. [interactive]. [accessed on 5-25-2013]. $<$ http://www.latvianforyou.com/cgi-bin/l. $\mathrm{pl}$ ? word $=$ sapr $\% \mathrm{C} 3 \% \mathrm{~A} 2 \mathrm{t} \% \mathrm{C} 3 \% \mathrm{AEgs} \& \mathrm{p}$ os $=583634>$.

Latvijas Republikas Augstākās Tiesas Senāta Krimināllietu Departamenta 2007. gada 11. janvāra lēmums lietā SKK -15/2007. 2007 [interactive]. [accessed on 5-252013]. <www.at.gov.lv/files/archive/ department2/2007/kd110107.doc $>$.

McBride, J. Human Rights and Criminal Procedure. The Case Law of the European Court of Human Rights. Council of Europe Publishing, 2009.

Meikališa, Ā.; Kazaka, S.; Lodīte, I. \& Petrova, S. Kriminālprocesuālie Termiņi Pirmstiesas Izmeklēšanā. Rīga: Petrovskis un Ko, 2006, p. 47.

Meikališa, Ā. \& Strada-Rozenberga, K. Pārmaiṇu Laiks Kriminālprocesā Turpinās. Jurista Vārds. 2009, 26 (579).

Mits, M. European Convention on Human Rights in Latvia. Lund: Media Tryck, 2010.

Osipova, S. Ievads Tiesību Sociologijīā. Rīga: Tiesu Namu Aǵentūra, 2010. p. 111. 
Pim, A. The Right to Trial within a Reasonable Time and Short-Term Reform of the European Court of Human Rights. Round Table Organised by the Slovenian Chairmanship of the Committee of Ministers of the Council of Europe. Bled, Slovenia, 21-22 September 2009, p. 26. [interactive]. [accessed on 5-25-2013]. <http://www. coe.int/t/dghl/standardsetting/cddh/ Publications/bledproceedings_book.pdf $>$.

Recommendation Nr. R (87) 18 of the Committee of Ministers of the Council of Europe on The Simplification of Criminal Justice. 1987.

Regina $v$ Smith, 4 AER 289. 2000 [interactive]. [accessed on 5-25-2013].

Senate's Decision of the Highest Court of Latvia Nr. SKK-95/2012 of 13 March, 2012.

Senate's Decision of the Highest Court of Latvia Nr.SKK-5/11 of 5 March, 2011.

Statistikas Pārskats par Krimināllietu Izskatī̌̌sanas Ilgumu Apelācijas Instancēe Apgabaltiesās 2012. Gadā.2012[interactive]. [accessed on 5-25-2013]. <http://www. ta.gov.lv/UserFiles/1366962759_Krim_ilg_ apel_2012.pdf $>$.

Statistikas Pārskats par Krimināllietu Izskatī̌̌anas Ilgumu Pirmajā Instancē Latvijas Tiesās 2012. Gadā. 2012 [interactive]. [accessed on 5-25-2013]. $<$ http://www.ta.gov.lv/UserFiles/1366 962720_Krim_ilg_1i_2012.pdf $>$.

Štariene, L. The Limits of the Use of UndercoverAgents and the Right to a Fair Trial under Article 6(1) of the European Convention of Humna Rights. Jurisprudencija. 2009, 3(117): 263-281.

Tiesu Varas Neatkarības un Efektivitātes Palielināšanas un Nostiprināšanas Rezerves. 2010 [interactive]. [accessed on 5-25-2013]. <http://www.juristavards. $\mathrm{lv} /$ ?menu $=\mathrm{doc} \& \mathrm{id}=206150>$.

Trechsel, S. Human Rights in Criminal Proceedings. Oxford: Oxford University Press, 2005.

Van Djik, P. Theory and Practice of the European Convention on Human Rights. Antwerpen, Oxford: Intersentia, 2006.

Vitkauskas, D. \& Dikov, G. Protecting the Trial to a Fair Trial under the European Convention on Human Rights. Council of Europe. Strasbourg: 2012, p. 75.

Zalar, A. The Right to Trial within a Reasonable Time and Short-Term Reform of the European Court of Human Rights. Round Table Organised by the Slovenian Chairmanship of the Committee of Ministers of the Council of Europe. Bled, Slovenia, 2122 September, 2009. [interactive]. [accessed on 5-25-2013]. <http://www.coe.int/t/ dghl/standardsetting/cddh/Publications/ bledproceedings_book.pdf $>$.

Zappalà, S. Human Rights in International Criminal Proceedings. Oxford: Oxford University Press, 2005.

Evropejskaja konvencija o zashchite prav cheloveka i osnovnyh svobod. Statja 6. Pravo na spravedlivoe sudebnoe razbiratelstvo. Moskva: Rossijskaja akademija pravosudija. 2001 [interactive]. [accessed on 5-21-2013]. $<$ www.theECHR.ru/documents/manuals/ Article06/Article6.rtf.>.

Kommentarij $k$ Konvencii o zashchite prav cheloveka i osnovnyh svobod i praktike ee primenenija. Pod redakciej V. A. Tumanova i L. M. Jentina. 2006 [interactive]. [accessed on 5-25-2013]. <http://www.hri.ru/docs/? content $=$ doc\&id $=371>$. 


\title{
BAUDŽIAMOJO PROCESO BAIGIMAS PER PROTINGĄ TERMINĄ LATVIJOJE
}

\author{
Sandra Kaija
}

Tarptautinė Baltijos akademija, Latvija

Santrauka. Straipsnis skirtas aktualiems santykinai naujo Latvijoje baudžiamojo proceso instituto klausimams aptarti. Jo aktualumas grindžiamas poreikiu taikyti efektyvu baudžiamojo proceso mechanizma, kuris garantuotu žmogaus teises $\dot{i}$ baudžiamaji procesa per protinga termina realizaciją. Pateikta Europos Žmogaus Teisiu Teismo praktikos analize igalina daryti tam tikras išvadas, kurias bütina imti domen praktikoje tiriant baudžiamąsias bylas.

Šio darbo objektas - baudžiamojo proceso teises normos, teises ir teisiniai santykiai, besivystantys šiu normu pagrindu, kurie yra susije su tarptautiniu standartu žmogaus teisè $\dot{q}$ baudžiamaji procesa per protinga termina srityje igyvendinimu praktikoje.

Šiame straipsnyje analizuojama Europos Žmogaus Teisiu Teismo ir Latvijos teismy praktika, Europos Sajungos pasiekimai. Straipsnio autore aptaria naujausius Latvijos baudžiamojo proceso istatymo pakeitimus. Pristatyti teisines reglamentacijos pakeitimai identifikuoja, kad Latvijos istatymu leidejui yra labai svarbu užtikrinti pagarba žmogaus teisems ir jas saugoti, ypatingai tokias teises ir laisves, kurios minimos ir tarptautininose dokumentuose.

Protingo termino samprata gali büti detalizuojama ja papildant specialiosiomis konkretaus atvejo salygomis ir imant domen tokius kriterijus kaip bylos sudetingumas, kaltinamojo ir kompetentingu instituciju ar pareigūnu elgesys. Šie kriterijai autorès detaliai analizuojami.

Straipsnio pabaigoje pateikiamose išvadose nurodoma, kad baudžiamaji procesa reglamentuojančios teises normos, susijusios su teise i baudžiamaji procesa per protinga termina, turetu büti interpretuojamos atsižvelgiant i Europos Žmogaus Teisiu Teismo praktika. Tokia analize suteikia pagrinda laiku įvertinti bei, jei tai pasirodytu bütina, keisti Latvijos teisine baze šioje srityje.

Reikšminiai žodžiai: žmogaus teisés, baudžiamasis procesas, protingas terminas, baudžiamojo proceso užbaigimas.

Sandra Kaija, Tarptautinès Baltijos akademijos Teisès krypties doktorantūros programos direktorè, mokslinio žurnalo „Administrative and Criminal Justice“ redaktorių kolegijos pirmininkè, daktarè, profesorè. Tyrimų kryptys: baudžiamojo proceso teisè, teisinè konfliktologija, kriminologija.

Sandra Kaija, Baltic International Academy, Dr. iur., Professor, director of a doctoral study programme Legal Science, chief editor of a scientific journal Administrative and Criminal Justice. Research interests: criminal procedure law, legal conflictology, criminology. 